\title{
Preparation of Antioxidant Enzymatic Hydrolysates from Honeybee-Collected Pollen Using Plant Enzymes
}

\author{
Margarita D. Marinova and Bozhidar P. Tchorbanov \\ Institute of Organic Chemistry with Centre of Phytochemistry, Bulgarian Academy of Sciences, Acad. G. Bonchev Street, \\ Building 9, BG-1113 Sofia, Bulgaria \\ Correspondence should be addressed to Margarita D. Marinova, m.d.marinova@abv.bg
}

Received 14 June 2010; Accepted 16 December 2010

Academic Editor: A. Pandey

Copyright (C 2010 M. D. Marinova and B. P. Tchorbanov. This is an open access article distributed under the Creative Commons Attribution License, which permits unrestricted use, distribution, and reproduction in any medium, provided the original work is properly cited.

Enzymatic hydrolysates of honeybee-collected pollen were prepared using food-grade proteinase and aminopeptidases entirely of plant origin. Bromelain from pineapple stem was applied ( $8 \mathrm{mAU} / \mathrm{g}$ substrate) in the first hydrolysis stage. Aminopeptidase $(0.05 \mathrm{U} / \mathrm{g}$ substrate) and proline iminopeptidase $(0.03 \mathrm{U} / \mathrm{g}$ substrate) from cabbage leaves (Brassica oleracea var. capitata), and aminopeptidase ( $0.2 \mathrm{U} / \mathrm{g}$ substrate) from chick-pea cotyledons (Cicer arietinum L.) were involved in the additional hydrolysis of the peptide mixtures. The degree of hydrolysis $(\mathrm{DH})$, total phenolic contents, and protein contents of these hydrolysates were as follows: DH (about 20-28\%), total phenolics (15.3-27.2 $\mu \mathrm{g} / \mathrm{mg}$ sample powder), and proteins (162.7-242.8 $\mu \mathrm{g} / \mathrm{mg}$ sample powder), respectively. The hydrolysates possessed high antiradical scavenging activity determined with DPPH (42-46\% inhibition). The prepared hydrolysates of bee-collected flower pollen may be regarded as effective natural and functional dietary food supplements due to their remarkable content of polyphenol substances and significant radical-scavenging capacity with special regard to their nutritional-physiological implications.

\section{Introduction}

Natural products and preparations for food and nutritional supplementation or dietary purposes have gained increased attention in recent years. Among them, honeybee-derived apicultural products, such as pollen, have been applied for centuries in alternative medicine as well as in food diets and supplementary nutrition due to their nutritional and physiological properties. Each pollen has its own specificity, mainly linked to the floral species or cultivars. Bee-collected pollens contain nutritionally essential substances including carbohydrates, proteins, amino acids, lipids, vitamins, mineral substances, and trace elements, but also significant amounts of polyphenol substances mainly flavonoids which, furthermore, are regarded as principal indicating ingredient substances of pollen and can be used for setting up quality standards in relation to their nutritional-physiological properties and for quality control of commercially distributed pollen preparations [1-4]. It is well known that polyphenols are responsible for the antioxidative and radical scavenging activity of plant food $[5,6]$. An antioxidant defense system protects cells from the injurious effects of free radicals. Furthermore, the biological, biochemical, physiological, pharmaceutical, and medicinal properties of polyphenol compounds have been extensively studied and have been reviewed by Rice-Evans et al. [7] in regard to their free-radical scavenging activity and multiple biological activities including vasodilatory, anticarcinogenic, anti-inflammatory, antibacterial, immunestimulating, antiallergic, antiviral, and estrogenic effects, as well as being inhibitors of specific enzymes.

On the basis of these reports, we have prepared watersoluble fractions from honeybee-collected pollen and investigated their functional properties. As a result, high freeradical scavenging activities against the DPPH free radical were exhibited. These results are comparable to the results reported for the antioxidant activities in red grapes (Vitis vinifera, L.) extracts [8, 9]. Moreover, we showed that enzymatic hydrolysates from honeybee-collected pollens possessed even higher antioxidative properties. In the present 
study, our aim was to prepare enzymatic hydrolysates from honeybee-collected pollens using plant proteinase and aminopeptidases and, then, to investigate the antioxidant activities in these peptide samples.

\section{Materials and Methods}

2.1. Materials. The pollen loads were collected in 2009 from the Ajtos area by honeybee colonies (Apis mellifera) settled in hives with bottom-fitted pollen traps. The aminopeptidase and proline iminopeptidase from cabbage leaves (Brassica oleracea var. capitata) and the aminopeptidase from chick-pea cotyledons (Cicer arietinum L.) were purified as described by Marinova et al. [10, 11]. Bromelain from pineapple stems (EC 3.4.22.4, $2 \mathrm{mAnsonU} / \mathrm{mg}$ ), L-amino acid $p$-nitroanilides, Folin-Ciocalteu, and 1,1-diphenyl-2picrylhydrazyl (DPPH), were purchased from Sigma-Aldrich Co. (St. Louis, USA).

\subsection{Methods}

2.2.1. Preparation of Enzymatic Hydrolysates from HoneybeeCollected Pollen. Honeybee-collected pollens (28\% protein) were added, suspended in 5 volumes of distilled water, and homogenized (Ultra-Turax, IKA-Werke, Germany), and $\mathrm{pH}$ of the suspension was adjusted at 7.0 using $\mathrm{NH}_{4} \mathrm{OH}$. The digestion was started by addition of $8 \mathrm{mAU} / \mathrm{g}$ bromelain at $37^{\circ} \mathrm{C}$. After 4 hours, hydrolysis was stopped by boiling in a microwave for 2 minutes. The additional hydrolysis was carried out by adding aminopeptidase ( 0.05 units/g substrate) and proline iminopeptidase ( 0.03 units/g substrate) from cabbage leaves as well as aminopeptidase from chickpea cotyledons ( 0.2 units/g substrate) and incubating for two hours at $37^{\circ} \mathrm{C}$ and $\mathrm{pH} 7.5$ with constant stirring. Hydrolysis was stopped by boiling in a microwave for 2 minutes. The obtained hydrolysates were centrifuged at $6000 \times \mathrm{g}$ for $30 \mathrm{~min}$ at $5^{\circ} \mathrm{C}$ (MLW K24 D, Germany) to remove the residue. The supernatant fractions were collected and freezedried.

2.2.2. Assays of Enzymes' Activities, Total Nitrogen, Total Protein, and Total Phenolic Compounds. Aminopeptidases' activities were determined using L-leucine- $p$-nitroanilides as substrate [12]. After incubation for $10 \mathrm{~min}$ at $30^{\circ} \mathrm{C}$ in $0.05 \mathrm{M}$ sodium phosphate buffer ( $\mathrm{pH} 7.2-7.5$ ), the liberated p-nitroaniline was measured at $410 \mathrm{~nm}$ on a spectrophotometer (UV-VIS Spectrophotometer, Shimadzu 1240). The iminopeptidase activity was assayed spectrophotometrically at $410 \mathrm{~nm}$ against L-proline-p-nitroanilide (Pro- $p$-NA) in $0.1 \mathrm{M}$ Tris/ $\mathrm{HCl}$ buffer ( $\mathrm{pH} 8.0$ ) for $20 \mathrm{~min}$ at $30^{\circ} \mathrm{C}$ [13]. One unit of enzyme activity was defined as the amount of enzyme releasing $1 \mu \mathrm{mol}$ of $p$-nitroaniline per minute.

The total protein content of the honeybee-collected pollen was determined by the method of Kjeldahl using the equation: $N \times 6.25$, where $N$ is the total Kjeldahl nitrogen multiplied by a factor to arrive at protein content [14]. The protein concentration of the samples after hydrolysis was measured according to the method of Lowry et al. [15], using bovine serum albumin as standard. The total phenolic content was determined by the Folin-Ciocalteu colorimetric method using catechin as standard, and the absorbance was measured at $760 \mathrm{~nm}$ [16].

2.2.3. Radical Scavenging Activity. The antiradical power of bee-collected pollen and pollen hydrolysates was evaluated in terms of the hydrogen-donating or radical-scavenging ability by the DPPH method [17], which is related to the inhibition in the initiation step of free radical processes. DPPH (2,2-diphenyl-1- picrylhydrazyl) is a stable free radical that accepts an electron or hydrogen radical to become a stable diamagnetic molecule and, accordingly, is reduced in presence of an antioxidant $(\mathrm{AH})$ :

$$
\mathrm{DPPH}^{\bullet}+\mathrm{AH} \longrightarrow \mathrm{DPPH}-\mathrm{H}+\mathrm{A}^{\bullet} .
$$

For the evaluation of the antioxidant activity of specific compounds or extracts, they are allowed to react with the stable DPPH radical in a methanol solution. In its radical form, DPPH has a characteristic absorbance at $515 \mathrm{~nm}$, which disappears upon reduction by $\mathrm{H}$ gained from an antioxidant compound.

For the test, appropriate methanol stock solutions of the pollen preparations $(500 \mathrm{mg} / \mathrm{L})$ and $\mathrm{DPPH}\left(6 \times 10^{-5} \mathrm{~mol} / \mathrm{L}\right)$ were prepared. Immediately after adding $0.3 \mathrm{~mL}$ of the pollen extract solution to $2.7 \mathrm{~mL}$ of the DPPH solution, the reduction of the DPPH-radical was measured by monitoring continuously the decrease of absorption at $515 \mathrm{~nm}$ in the dark until stable absorption values were obtained (30 min). The antiradical activity was determined in terms of PI values (\% inhibition) which was calculated by the ratio of the decrease of absorption of the DPPH-pollen extract test solution after a 30 -minute reaction time (stable phase) to the absorption value of the reference sample where an equivalent volume of methanol was added, as defined according to the formula:

$$
\mathrm{PI}(\% \text { inhibition })=\left[A_{0}-\frac{A_{\mathrm{t}}}{A_{0}}\right] \times 100,
$$

where $A_{0}$ is the absorbency of the DPPH-methanol solution (reference) and $A_{t}$ is the absorbency of the DPPH-pollen extract solution after $30 \mathrm{~min}$ of reaction time.

2.2.4. SDS-Polyacrylamide Gel Electrophoresis. Sodium dodecyl sulfate polyacrylamide gel electrophoresis (SDS-PAGE) was performed in $15 \%$ polyacrylamide gel using Trisglycine buffer, $\mathrm{pH} 8.3$, according to Laemmli [18]. Rabbit muscle myosin (205 kDa), $\beta$-galactosidase $(116 \mathrm{kDa})$, rabbit muscle phosphorylase b $(97 \mathrm{kDa})$, bovine serum albumin $(66 \mathrm{kDa})$, lactate dehydrogenase $(36.5 \mathrm{kDa})$, carbonic anhydrase $(29 \mathrm{kDa})$, trypsin inhibitor $(20 \mathrm{kDa})$, lysozyme $(14 \mathrm{kDa})$, aprotinin $(6.1 \mathrm{kDa})$, insulin a $(3.4 \mathrm{kDa})$, and insulin $\mathrm{b}(2.4 \mathrm{kD})$ were used as molecular weight marker proteins. The gel was visualized by silver staining [19].

2.2.5. Determination of the Degree of Hydrolysis (DH) and Amino Acid Composition. The degree of hydrolysis was 
TABLE 1: The contents of protein and total phenolic components of enzymatic hydrolysates from honeybee-collected pollen.

\begin{tabular}{lccc}
\hline Sample & Protein $(\mu \mathrm{g} / \mathrm{mg}$ sample $)$ & Total phenols $(\mu \mathrm{g} / \mathrm{mg}$ sample $)$ & PI-value $(\%)$ \\
\hline Bee-pollen & $162.7 \pm 0.2$ & $15.3 \pm 0.3$ & $28 \pm 2$ \\
${ }^{1} \mathrm{BH}$ & $227.1 \pm 0.3$ & $21.5 \pm 0.6$ & $40 \pm 1$ \\
${ }^{2} \mathrm{APH}_{1}$ & $238.8 \pm 0.5$ & $25.6 \pm 0.7$ & $44 \pm 2$ \\
${ }^{3} \mathrm{APH}_{2}$ & $230.5 \pm 0.6$ & $24.1 \pm 0.9$ & $42 \pm 2$ \\
${ }^{4} \mathrm{APH}_{3}$ & $242.8 \pm 0.5$ & $27.2 \pm 0.6$ & $46 \pm 1$ \\
\hline
\end{tabular}

${ }^{1} \mathrm{BH}$ bromelain hydrolysate

${ }^{2} \mathrm{APH}_{1}$ cabbage aminopeptidase and proline iminopeptidase hydrolysate

${ }^{3} \mathrm{APH}_{2}$ chick-pea aminopeptidase hydrolysate

${ }^{4} \mathrm{APH}_{3}$ cabbage and chick-pea aminopeptidases hydrolysate

determined using 2,4,6-trinitrobenzenesulfonic acid [20]. A sample solution $(0.25 \mathrm{~mL})$ is mixed with $2.0 \mathrm{~mL}$ of $0.2 \mathrm{M}$ sodium phosphate buffer $(\mathrm{pH} 8.2)$ and $2.0 \mathrm{~mL}$ of $0.1 \%$ trinitrobenzenesulfonic acid, followed by incubation in the dark for $60 \mathrm{~min}$ at $50^{\circ} \mathrm{C}$. The reaction is quenched by adding $4.0 \mathrm{~mL}$ of $0.1 \mathrm{~N} \mathrm{HCl}$, and the absorbance is read at $340 \mathrm{~nm}$. A $1.5 \mathrm{mM} \mathrm{L}$-leucine solution is used as the standard. Transformation of the measured leucine amino equivalents to degree of hydrolysis is carried out by means of a standard curve for each particular protein substrate.

The amino acid composition was determined after 50 min of hydrolysis at $165^{\circ} \mathrm{C}$ with $6 \mathrm{~N} \mathrm{HCl}$, and the analysis was performed on HPLC Nova-Pak C18 $(3.9 \times 150 \mathrm{~mm}$, $4 \mu \mathrm{m}$, Waters). The mobile phase consisted of eluent A (prepared from Waters AccQ-Tag Eluent A concentrate, by adding $200 \mathrm{~mL}$ of concentrate to $2 \mathrm{~L}$ of Milli-Q water and mixing), eluent B (acetonitrile, HPLC grade), and eluent C (Milli-Q water). The following conditions were used: linear gradient of $100-0 \%$ eluent $\mathrm{A}, 0-60 \%$ eluent $\mathrm{B}$, and $0-40 \%$ eluent $\mathrm{C}$ in $30 \mathrm{~min}$ and then isocratic $100 \%$ of eluent $\mathrm{A}$ for $20 \mathrm{~min}$ with a flow rate of $1 \mathrm{~mL} / \mathrm{min}$.

\section{Results and Discussion}

3.1. The Total Phenolic Contents and Protein Contents of Enzymatic Hydrolysates from Bee Pollen. The enzymatic hydrolysates from bee pollen were digested and prepared using plant proteinase bromelain, and aminopeptidases from cabbage leaves and chick-pea cotyledons. SDS-PAGE analysis indicated that the pollen was perfectly digested by these enzymes (Figure 1). The degrees of hydrolysis of the beepollen hydrolysates were as follows: about $20 \%$ for the bromelain hydrolysate (BH), 26\% for the cabbage aminopeptidase and proline iminopeptidase hydrolysate $\left(\mathrm{APH}_{1}\right), 24 \%$ for the chick-pea aminopeptidase hydrolysate $\left(\mathrm{APH}_{2}\right)$, and $28 \%$ for the hydrolysate obtained by the combination of aminopeptidases from cabbage and chick-pea $\left(\mathrm{APH}_{3}\right)$. Total phenolic contents of these hydrolysates were as follows: $21.5 \mu \mathrm{g} / \mathrm{mg}$ sample $(\mathrm{BH}), 25.6 \mu \mathrm{g} / \mathrm{mg}$ sample $\left(\mathrm{APH}_{1}\right)$, $24.1 \mu \mathrm{g} / \mathrm{mg}$ sample $\left(\mathrm{APH}_{2}\right)$, and $27.2 \mu \mathrm{g} / \mathrm{mg}$ sample $\left(\mathrm{APH}_{3}\right)$, respectively (Table 1 ). On the other hand, the protein contents of these hydrolysates were as follows: $227.1 \mu \mathrm{g} / \mathrm{mg}$ sample $(\mathrm{BH}), 238.8 \mu \mathrm{g} / \mathrm{mg}$ sample $\left(\mathrm{APH}_{1}\right), 230.5 \mu \mathrm{g} / \mathrm{mg}$ sample $\left(\mathrm{APH}_{2}\right)$, and $242.8 \mu \mathrm{g} / \mathrm{mg}$ sample $\left(\mathrm{APH}_{3}\right)$, respectively

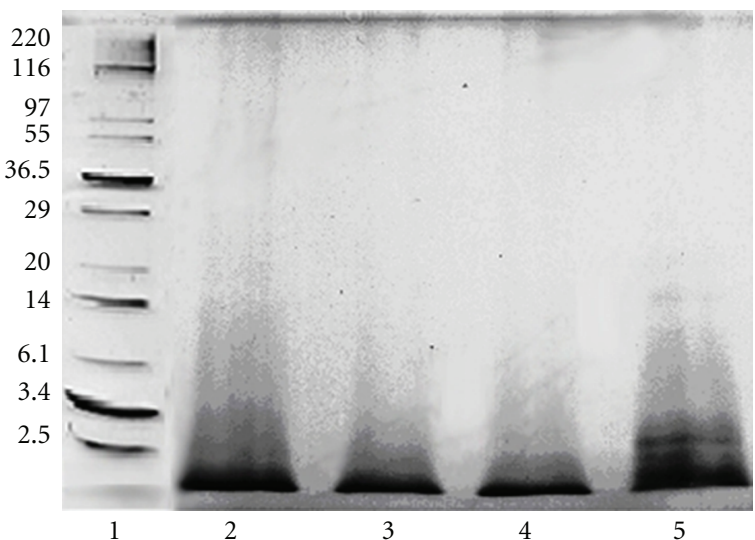

FIGURE 1: SDS-polyacrylamide gel electrophoresis of molecular weight markers and enzymatic hydrolysates from honeybeecollected pollen. (1) Molecular weight markers; (2) aminopeptidases hydrolysate (cabbage and chick-pea); (3) aminopeptidase and proline iminopeptidase hydrolysate (cabbage); (4) aminopeptidase hydrolysate (chick-pea); (5) bromelain hydrolysate.

(Table 1). It suggests that the protein contents correlated closely with the contents of total phenolic components.

3.2. DPPH Radical Scavenging Ability of Enzymatic Hydrolysates from Pollen. Although native bee-collected pollen water extract shows considerable antiradical activity (PI $=28 \%$ inhibition), the reduction of the DPPH radical was significantly increased by applying the obtained pollen hydrolysates (PI $=42-46 \%$ inhibition) as is shown in Table 1, which indicate an elevated free-radical scavenging efficiency of the pollen hydrolysates. The highest degree of radical scavenging capacity was assessed in the $\mathrm{APH}_{3}$ (PI $=46 \%$ inhibition) which, correspondingly, also has the highest concentration of polyphenol substances $(27.2 \mu \mathrm{g} / \mathrm{mg}$ sample powder). For this reason, it can be assumed that there is a general correlation between the content of total polyphenolics and the free-radical scavenging capacity of the pollen preparations.

Although, in comparison, tests with equivalent amount of the synthetic antioxidant gallic acid shows higher PI values of approximately $90 \%$, it must be taken into consideration 
TABle 2: The amino acids composition of honeybee-collected pollen and bee-pollen hydrolysate obtained by the combination of aminopeptidases from cabbage and chick-pea $(*)$.

\begin{tabular}{lcc}
\hline Amino acids & C (\%) & C* $\%)$ \\
\hline Asp & 7.5 & 6.6 \\
Hyp & 1.5 & 1.5 \\
Glu & 8.6 & 7.8 \\
Ser & 5.8 & 5.9 \\
Gly & 9.8 & 10.5 \\
His + Thr & 5.1 & 5.0 \\
Ala & 8.0 & 7.9 \\
Arg & 4.6 & 1.0 \\
Pro & 17.1 & 22.2 \\
Tyr & 1.7 & 1.4 \\
Val & 6.7 & 6.7 \\
Met & 2.2 & 2.1 \\
Ile & 5.3 & 5.1 \\
Leu & 7.9 & 7.5 \\
Lys & 3.4 & 2.6 \\
Phe & 8.1 & 5.5 \\
\hline
\end{tabular}

that pollen extract represents a concentrated nature-derived mixture of different active polyphenol compounds.

The results of the amino acids' composition for the beepollen extract and the pollen hydrolysate obtained by combination of aminopeptidases from cabbage and chick-pea are shown in Table 2. Relatively high content of hydrophobic amino acids Pro, Phe, and Gly is characteristic for the beepollen extract and the $\mathrm{APH}_{3}$. The amounts of these amino acids in bee-pollen hydrolysate after a 6-hour hydrolysis are approximately $22,5.5$ and $10.5 \%$, respectively of the total content.

The honeybee products are considered to be abundant sources of antioxidants. In honey, royal jelly, propolis, and bee pollens high antioxidant activity was found [21]. In bee-collected pollen water extracts high radical-scavenging activity, activity against superoxide anion, and hydroxyl radical-scavenging activity were reported [22-25].

Antioxidative ability of pollen seems to be due to phenolic compounds. In the present investigations, a very high antioxidant activity, expressed as radical-scavenging activity corresponded to high levels of total phenols, was found in water-soluble extract and in plant proteinase and aminopeptidases hydrolysates.

\section{Conclusion}

The use of honeybee-collected pollens as an alternative medicine is increasing due to their biologically active properties that make them attractive as a source of essential amino acids, vitamins, minerals, and antioxidants in human diets. The useful components from honeybee-collected pollen can be fully digested using the food-grade enzymes such as bromelain, cabbage aminopeptidase and proline iminopeptidase, and chick-pea aminopeptidase, although it is not easy to digest honeybee-collected pollen with a hard cell wall. In this process, consumer demand of honeybee-collected pollen for natural foods with medicinal effects such as antioxidative activity is increasing.

In conclusion, pollen extracts represent a concentrated nature-derived mixture of different active polyphenol compounds which, according to practical applications as a bioactive diet component, are usually applied and consumed in higher amounts than the pure synthetic antioxidant food additives.

\section{Acknowledgment}

The authors thank the National Foundation for Scientific Research for financial support of Project TK-X 1608.

\section{References}

[1] B. M. Talpay, Der Pollen, Eigenverlag Institut für Honigforschung, Bremen, Germany, 1981.

[2] R. G. Stanley and H. F. Linskens, Pollen: Biologie, Biochemie, Gewinnung und Verwendung, Urs Freund, Greifenberg, Germany, 1985.

[3] G. Kroyer, "Flavonoids and phytosterols as bioactive substances in dietary applied pollen products," in Proceedings of Euro Food Chem X: Functional Foods-A New Challenge for the Food Chemists, pp. 102-108, Publishing Company of TUB, Budapest, Hungary, 1999.

[4] J. Kanner, E. Frankel, R. Granit, B. German, and J. E. Kinsella, "Natural antioxidants in grapes and wines," Journal of Agricultural and Food Chemistry, vol. 42, no. 1, pp. 64-69, 1994.

[5] N. Salah, N. J. Miller, G. Paganga, L. Tijburg, G. P. Bolwell, and C. Rice-Evans, "Polyphenolic flavanols as scavengers of aqueous phase radicals and as chain-breaking antioxidants," Archives of Biochemistry and Biophysics, vol. 322, no. 2, pp. 339-346, 1995.

[6] J. A. Vinson and B. A. Hontz, "Phenol antioxidant index: comparative antioxidant effectiveness of red and white wines," Journal of Agricultural and Food Chemistry, vol. 43, no. 2, pp. 401-403, 1995.

[7] C. A. Rice-Evans, N. J. Miller, and G. Paganga, "Structureantioxidant activity relationships of flavonoids and phenolic acids," Free Radical Biology and Medicine, vol. 20, no. 7, pp. 933-956, 1996.

[8] V. Briedis, V. Povilaityte, S. Kazlauskas, and P. R. Venskutonis, "Polyphenols and anthocyanins in fruits, grapes juices and wines, and evaluation of their antioxidant activityPolifenoliu ir antocianinu kiekis vynuogese, vynuogiu sultyse ir raudonuose vynuose bei ju antioksidacinio aktyvumo ivertinimas," Medicina, vol. 39, pp. 104-112, 2003.

[9] C. H. Chen, M. C. Wu, C. Y. Hou, C. M. Jiang, C. M. Huang, and Y. T. Wang, "Effect of phenolic acid on antioxidant activity of wine and inhibition of pectin methyl esterase," Journal of the Institute of Brewing, vol. 115, no. 4, pp. 328-333, 2009.

[10] M. Marinova, A. Dolashki, F. Altenberend, S. Stevanovic, W. Voelter, and B. Tchorbanov, "Characterization of an aminopeptidase and a proline iminopeptidase from cabbage leaves," Zeitschrift fur Naturforschung, vol. 63, no. 1-2, pp. 105$112,2008$.

[11] M. Marinova, A. Dolashki, F. Altenberend, S. Stevanovic, W. Voelter, and B. Tchorbanov, "Purification and characterization of L-phenylalanine aminopeptidase from chick-pea 
cotyledons (Cicer arietinum L.)," Protein and Peptide Letters, vol. 16, no. 2, pp. 207-212, 2009.

[12] M. J. Chrispeels and D. Boulter, "Control of storage protein metabolism in the cotyledons of germinating mung beans: role of endopeptidase," Plant Physiology, vol. 55, pp. 1031-1037, 1975.

[13] T. Yoshimoto and D. Tsuru, "Proline iminopeptidase from Bacillus coagulans: purification and enzymatic properties," Journal of Biochemistry, vol. 97, no. 5, pp. 1477-1485, 1985.

[14] P. L. Kirk, "Kjeldahl method for total nitrogen," Analytical Chemistry, vol. 22, no. 2, pp. 354-358, 1950.

[15] O. H. Lowry, N. J. Rosebrough, A. L. Farr, and R. J. Randall, "Protein measurement with the Folin phenol reagent," The Journal of Biological Chemistry, vol. 193, no. 1, pp. 265-275, 1951.

[16] K. Slinkard and V. L. Singleton, "Total phenol analysis," American Journal of Enology and Viticulture, vol. 28, pp. 4955, 1977.

[17] W. Brand-Williams, M. E. Cuvelier, and C. Berset, "Use of a free radical method to evaluate antioxidant activity," Food Science and Technology, vol. 28, no. 1, pp. 25-30, 1995.

[18] U. K. Laemmli, "Cleavage of structural proteins during the assembly of the head of bacteriophage T4," Nature, vol. 227, no. 5259, pp. 680-685, 1970.

[19] D. W. Sammmons, L. D. Adams, and E. E. Nishizawa, "Ultrasensitive silver-based color staining of polypeptides in polyacrylamide gels," Electrophoresis, vol. 2, pp. 135-141, 1980.

[20] J. Adler-Nissen, "Determination of the degree of hydrolysis of food protein hydrolysates by trinitrobenzenesulfonic acid," Journal of Agricultural and Food Chemistry, vol. 27, no. 6, pp. 1256-1262, 1979.

[21] T. Nagai, M. Sakai, R. Inoue, H. Inoue, and N. Suzuki, "Antioxidative activities of some commercially honeys, royal jelly, and propolis," Food Chemistry, vol. 75, no. 2, pp. 237240, 2001.

[22] M. G. Campos, R. F. Webby, and K. R. Markham, "The unique occurrence of the flavone aglycone tricetin in Myrtaceae pollen," Zeitschrift fur Naturforschung C, vol. 57, no. 9-10, pp. 944-946, 2002.

[23] M. G. Campos, R. F. Webby, K. R. Markham, K. A. Mitchell, and A. P. Da Cunha, "Age-induced diminution of free radical scavenging capacity in bee pollens and the contribution of constituent flavonoids," Journal of Agricultural and Food Chemistry, vol. 51, no. 3, pp. 742-745, 2003.

[24] M. Leja, A. Mareczek, G. Wyzgolik, J. Klepacz-Baniak, and K. Czekońska, "Antioxidative properties of bee pollen in selected plant species," Food Chemistry, vol. 100, no. 1, pp. 237-240, 2007.

[25] T. Nagai, R. Inoue, N. Suzuki, T. Myoda, and T. Nagashima, "Antioxidative ability in a linoleic acid oxidation system and scavenging abilities against active oxygen species of enzymatic hydrolysates from pollen Cistus ladaniferus," International Journal of Molecular Medicine, vol. 15, no. 2, pp. 259-263, 2005. 

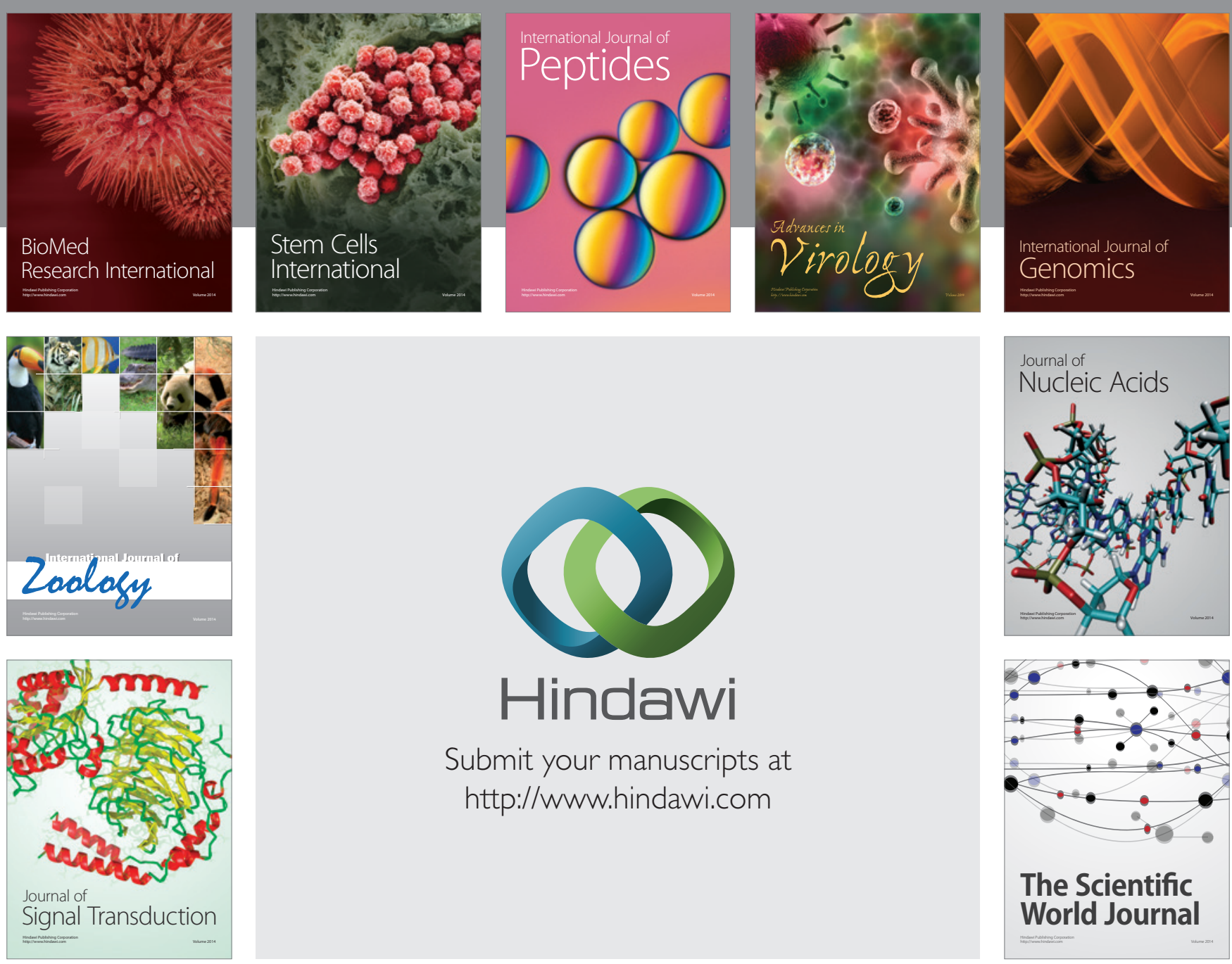

Submit your manuscripts at

http://www.hindawi.com
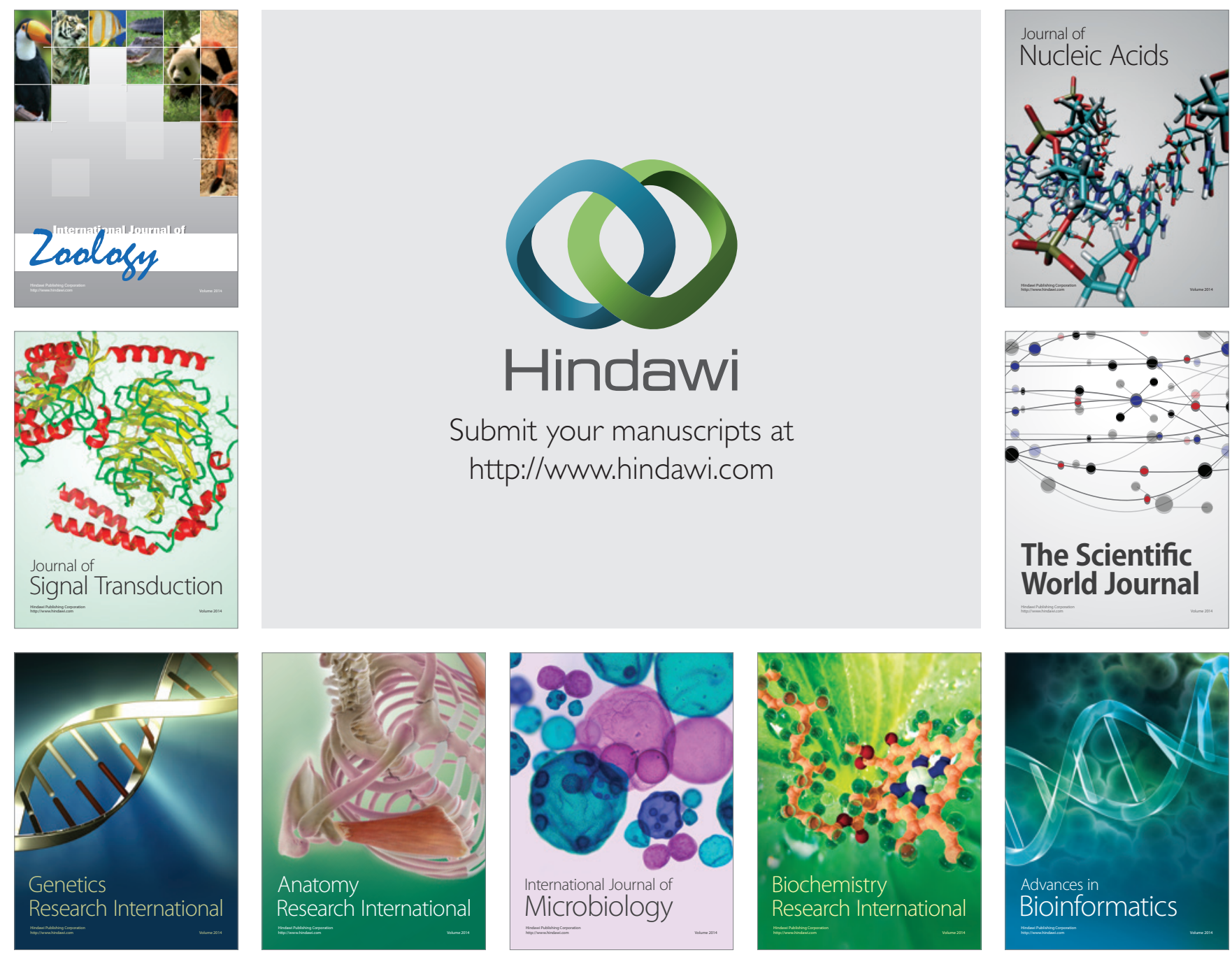

The Scientific World Journal
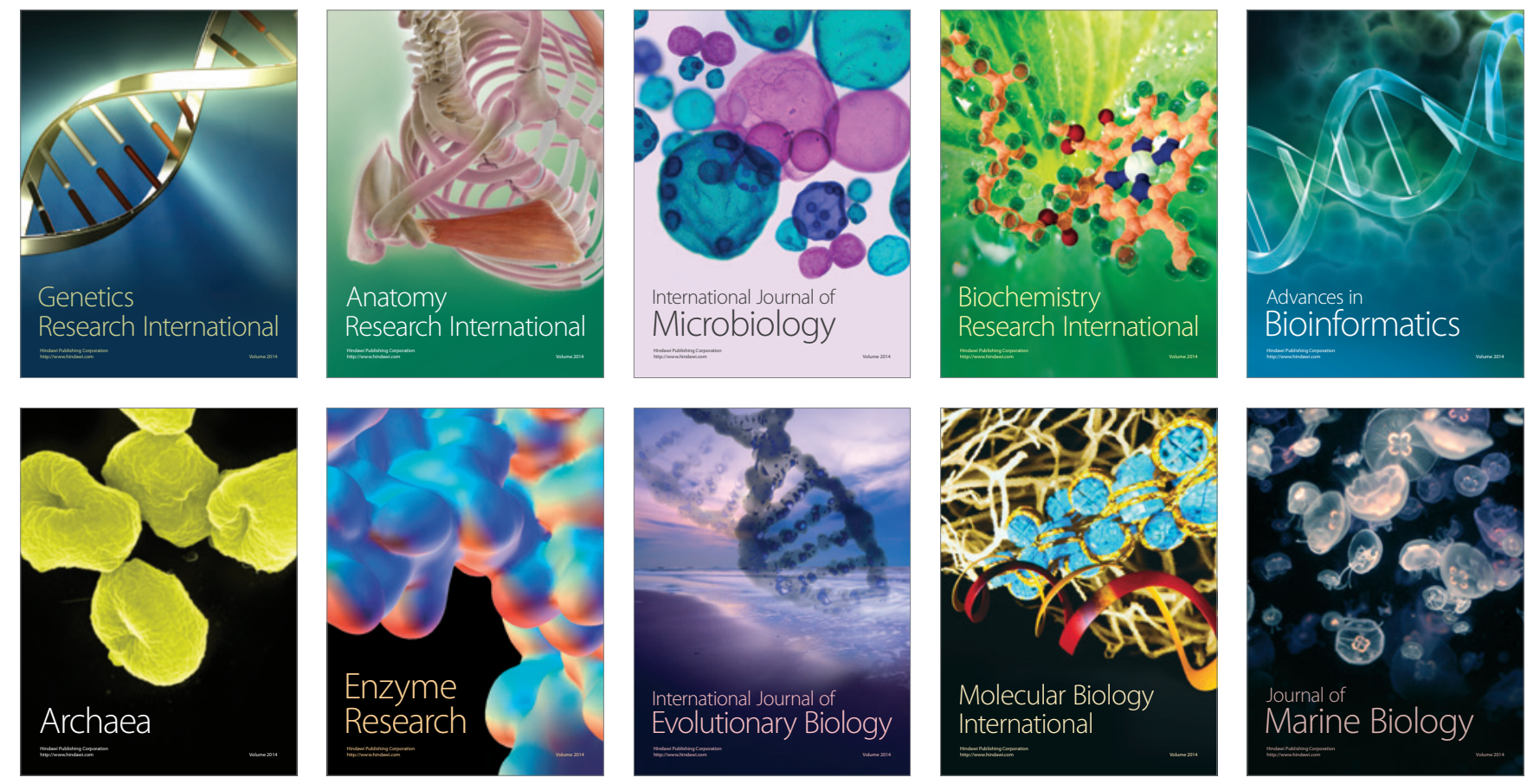